\title{
CNC Milling and Manufacturing of Groove Shapes for Light Reflection Measurement
}

Ondrej Bilek ${ }^{1}$, Martin Vasina ${ }^{1,2}$

${ }^{1}$ Faculty of Technology, Tomas Bata University in Zlín. T. G. Masaryka 5555, 76001 Zlin. Czech Republic. E-mail: bilek@ft.utb.cz,vasina@ft.utb.cz

${ }^{2}$ Faculty of Mechanical Engineering, VSB-Technical University of Ostrava. 17. listopadu 15/2172, 70833 Ostrava-Poruba. Czech Republic. E-mail: martin.vasina@vsb.cz

Light reflection of materials depends on many factors, mainly on their colour and type, angle of light incidence and surface structure. This paper is focused on evaluation of the surface shape influence of expanded polyvinylchloride on light reflection. For this reason polyvinylchloride samples with different shapes, depths, widths and numbers of surface grooves were produced on CNC milling machine. The light reflection of the investigated material samples was experimentally measured by means of illuminance ratio. The samples were subsequently compared in terms of their ability to reflect light. A part of the work deals with mathematical simulation of the daylight factor for definite surface shapes. The simulations were performed using Wdls 4.1 software. It was found that the surface shape has an influence on the light reflection and on the illuminance in a given point too. The light reflection of the tested material is in general influenced by shape, depth, width and number of surface unevenesses.

Keywords: Light Reflection, CNC Milling, Daylight Factor, Surface Shape, Polyvinylchloride.

\section{References}

[1] BYSTRICKY, V., KANKA, J. (1994). Osvetleni. 76 p. CVUT, Praha (in Czech).

[2] NARISADA, K., SCHREUDER, D. (2004). Light Pollution Handbook. 945 p. Springer, Netherlands.

[3] CSN 36 0011-1, (2006) Mereni osvetleni vnitrnich prostoru - Cast 1: Zakladni ustanoveni. Praha: Cesky normalizacni institut, (in Czech).

[4] VASILKO, Karol. New experimental dependence of machining. In: Manufacturing Technology. 2014, Vol. 14, No. 1, pp. 111-116. JEPU in Usti nad Labem. Czech Republic.

[5] SUBA, O., SYKOROVA, L., LUKOVICS, I. (2012) Stress analysis of injection - moulded cylindrical parts reinforced with short fibres. In: Manufacturing Technology, Vol. 12, No. 13, pp. 251-254. JEPU in Usti nad Labem. Czech Republic.

[6] LEGUTKO, S., KROLCZYK, G., KROLCZYK, J. (2014). Quality evaluation of surface layer in highly accurate manufacturing. In: Manufacturing Technology, Vol. 14, No. 1, pp. 50-56. JEPU in Usti nad Labem. Czech Republic.

[7] JOZWIK, J., KURIC, I., SAGA, M., LONKWIC, P. (2014) Diagnostics of CNC machine tools in manufacturing process with laser interferometer technology. In: Manufacturing Technology, Vol. 14, No. 1, pp. 23-30. JEPU in Usti nad Labem. Czech Republic.

[8] CHEL, A., TIWARI, G.N., SINGH, H.N. (2010). A modified model for estimation of daylight factor for skylight integrated with dome roof structure of mud-house in New Delhi (India). In: Applied Energy, Vol. 87, No. 10, pp. 3037 - 3050. Elsevier. England.

[9] CALCAGNI, B., PARONCINI, M. (2004). Daylight factor prediction in atria building designs. In: Solar Energy, Vol. 76, No. 6, pp. 669 - 682. Elsevier. England.

[10]REINHART, CH.F., HERKEL, S. (2000). The simulation of annual daylight illuminance distributions - a stateof-the-art comparison of six RADIANCE-based methods. In: Energy and Buildings, Vol. 32, No. 2, pp. 167 - 187. Elsevier. Netherlands.

[11] WDLS (2014). Vypocet denniho osvetleni dle CSN (STN) 73 0580. Available on: http://www.astrasw.cz/node/3 (in Czech) 